\title{
COMMENT ON "DIET-DERIVED VARIATIONS IN RADIOCARBON AND STABLE ISOTOPES: A CASE STUDY FROM SHAG RIVER MOUTH, NEW ZEALAND”"
}

\author{
Nancy Beavan Athfield \\ Rafter Radiocarbon Laboratory, National Isotope Centre, GNS Science, Lower Hutt, New Zealand. \\ Email: n.beavan@gns.cri.nz.
}

Higham et al.'s (2005) recent article in Radiocarbon 47(3) concerning diet-induced anomalies on radiocarbon ages for various faunal samples from Shag River Mouth is a well-considered study, building upon methodologies and research questions examining the phenomena of dietary anomalies addressed by Beavan Athfield and coauthors (cf. Beavan-Athfield et al. 1999, 2001a; BeavanAthfield and Sparks 2001a,b,c). However, exception must be taken with one comment appearing in Higham et al. (2005) that suggests to the reader that there is a problem with the laboratory practice associated with rat bone dates measured at the Rafter Radiocarbon Laboratory of GNS Science, New Zealand.

On pages 367-368 is the statement, “Anderson (2004) identified an 'age disconformity' in the main assemblage of rat bone dates, both natural and archaeological; ${ }^{14} \mathrm{C}$ determinations from both site types fall into the same age ranges when plotted against the period of processing in the Rafter Radiocarbon Laboratory, IGNS, which suggests an underlying laboratory problem, possibly in pretreatment." The "age disconformity" of Anderson (2004) first appeared in Anderson (2000:252), which included a graph of rat bone measurements produced over a specific time by the Rafter Laboratory. The graph suggested that between 1995-96 only ages over 1000 BP were produced, and post 1996, only ages younger than $\sim 1000 \mathrm{BP}$ were produced.

Beavan Athfield (2004) noted that there were a number of rat bone dates of less than 950 BP in that 1995-96 series. Anderson (2000:248) limits his consideration of acceptable ages for Rattus exulans bone to $~ 800$ BP ( 1200 AD), citing Anderson (1991) for the estimated basal age of prehistoric human settlement in New Zealand; for ease of comparison the same limit is considered here. In the actual 1995-96 series (i.e. up to Anderson's NZA 7000 limit), a total of 35 Rattus exulans bone measurements produced 9 results of between 236 and $895 \mathrm{BP}$, and 2 additional modern rat samples as internal tests (Figure 2). A few ages of less than $950 \mathrm{yr}$ previously listed in Beavan Athfield (2004) were found to be on protein extracts from soil on bones, and since they are not derived directly from bone, are deleted from Figure 2. Nevertheless, no measurements of less than 2950 BP appear to be included during the time span set in Anderson (2000:248-50), although the data for all but 3 samples in the 35 are published (Beavan-Athfield et al. 1999; Holdaway 1996, 1999; Holdaway and Anderson 1998).

A graph of actual AMS age production for rat bones measured between 1995-96 and 1997 to 1998 at the Rafter Laboratory was provided in Beavan Athfield (2004). In that paper, Anderson's “production trend" was compared to the actual production of rat bone ages over time (Beavan Athfield 2004:114-5). Anderson's "trend" (Figure 1) is, when actual rat bone data are plotted (Figure 2), an oscillation between older and younger dates in the period 1995-96, reflecting the effects of sample submission during the progress of internal laboratory checks and a research program to study faunal extinction and decline in late-Holocene New Zealand environments.

The Rafter Radiocarbon Laboratory began an informal review during the 1995-96 period given the remarkable number of ages for rat bone $>1000 \mathrm{BP}$. We examined these with a research program on diet-driven ${ }^{14} \mathrm{C}$ offsets (Beavan and Sparks 1998; Beavan Athfield et al. 1999), a review of Rafter laboratory method, and dating of known-age rat bone to check for possible contamination effects. In 


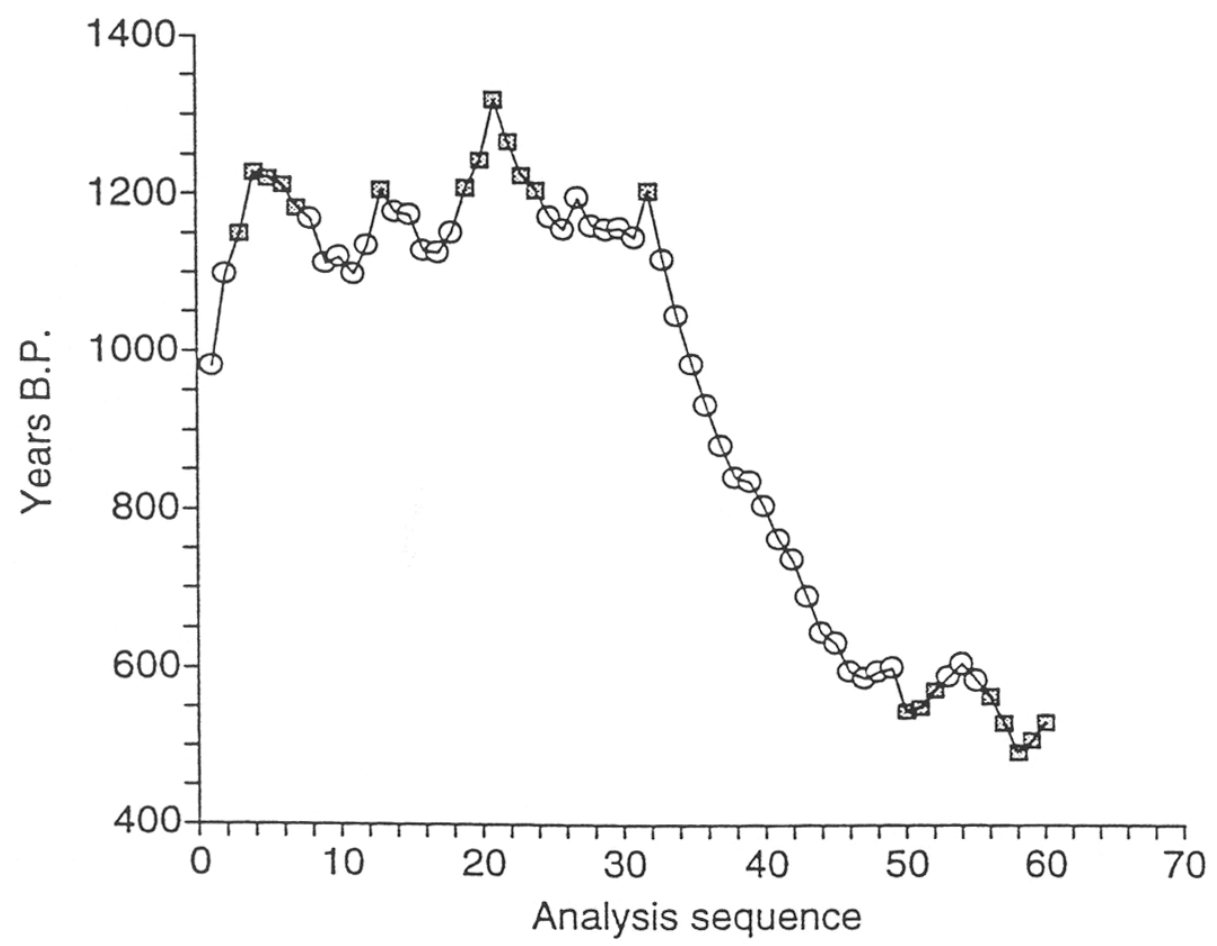

Figure 1 Reprint of Anderson (2000:252) "production trend" of ${ }^{14} \mathrm{C}$ ages on rat bone at the Rafter Radiocarbon Laboratory/GNS Science between 1995 and 1998. Anderson's determination of the end of the year 1996 (NZA 7000+) is at point 32. Archaeological results are shown as squares and natural/avian predator site results as circles. Exponentially weighted moving averages of AMS ages are plotted. The statistical method employed either obscures or misses 12 AMS dates on ancient rat bone of less than $\sim 950$ BP ( 1200 AD) produced before NZA 7000; all but 3 of these <950-BP ages were published by 1999.

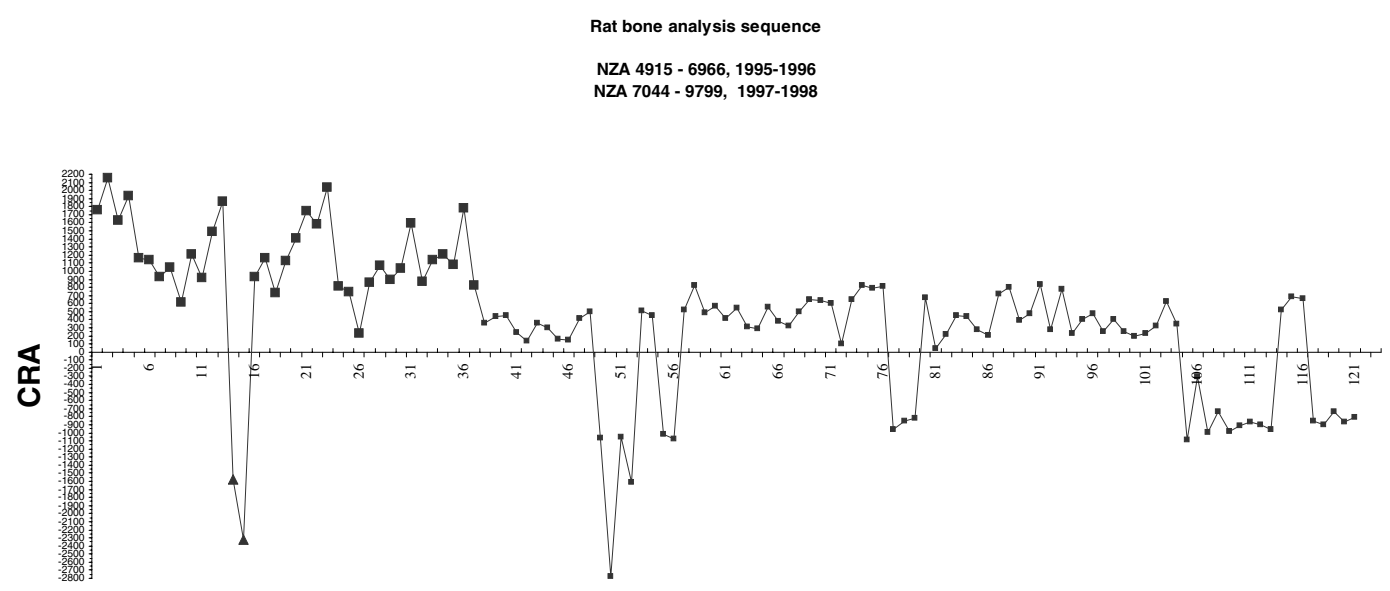

Figure 2 Rafter Radiocarbon AMS dates for rat bone (archaeological site, natural site, and modern rat) from 1996-1998. Production during 1995-1996 (large icons, points 1-37, in range of NZA 4915-6966) and 1997-1998 (points 38-121, in range of NZA 7044-9799). Twelve ages of less than 950 BP ( 1200 AD) were produced in the 1995-1996 series, including 9 results between 236 and $895 \mathrm{BP}$; two additional, bomb-carbon-induced results (triangles, points 14-15) are modern rat bone tested during 1995 to check for contamination in laboratory processing. Several ages of less than $950 \mathrm{yr}$ previously listed for this figure (Beavan Athfield 2004) were found to be on protein extracts from soil and are here deleted. 
1997, an external test was also submitted in the form of a powdered rat-bone experiment to 3 laboratories, including Rafter, to assess whether there was analytical bias among labs given identical aliquots (Anderson 2000:245). Rafter and Oxford "both produced reasonably similar determinations in the expected age range" as reported in Anderson (2000:247). When a third laboratory involved in the comparison indicated problems with their methodology that produced unreasonable results, Anderson commented that the "IGNS laboratory" could also have done a "tightening up" to effect an improvement in rat bone age determination by the time of the bone powder experiments (Anderson 2000:256-8).

In 1999, the Rafter Laboratory invited an independent review of past and present laboratory procedures, published in Hedges (2000). This citation has apparently been overlooked by Higham et al. (2005) but is pertinent to the comment that measurements on Rattus exulans of greater than $\sim 1200$ AD result from "an underlying laboratory problem." In fact, Hedges (2000:393-4) did note a concentration of old bone ages but could identify no such procedural problem, commenting:

There is a very significant correlation here, in that no recent measurements (since 1997) have produced

${ }^{14} \mathrm{C}$ ages greater than about 800 B.P. This immediately suggests the hypotheses that (1) before that time the methodology of the laboratory was in some way responsible for erroneous older dates, and that (2) something changed after that time, so that whatever was the cause ceased to operate. However, no change at all in the procedures was made in 1997, and indeed as mentioned already, there has been no significant change in the procedures throughout the dating programme. In any case, the experimental protocols at no time suggest a plausible explanation for the cause of erroneous dates.

Hedges (2000:394) also addressed the phenomena of ages that were mainly (but not exclusively) older than accepted human settlement dates in New Zealand of $\sim 1200$ AD being produced during a certain time frame:

The correlation ... can in fact be reasonably explained as a sampling artefact (i.e., that more recent submissions did not contain, and did not aim to contain, genuinely older material). There is no sign that older age is more likely for a given processing batch (other than the correlation of a batch with a particular site) or is associated with a particular run, or a particular operator.

Dr. Holdaway, the submitter of the rat bone samples, had stated that this was indeed the submission scheme to ascertain the oldest of bone deposits for each of his faunal sites (Holdaway and Worthy 2001; Holdaway et al. 2002). Higham and Petchey (2001:455) argued that this sampling process did not explain an "identical production trend (of anomalous ages)" in 4 rat bone results processed in 1995-96 from Shag River and 2 results from Pleasant River. At Pleasant River, Beavan-Athfield and Sparks (2001b) suggested that anomalous ages in rat and waterfowl could likely result from variable but unidentified "old carbon" diet influences, which if marine were not signaled by ${ }^{13} \mathrm{C}$ signatures. Higham et al. (2005) found a similar pattern in non-marine waterfowl species and rat bone at Shag River. Diet-induced variation at these sites could be significant; Higham et al. (2005:371) reports on variation and range in ${ }^{15} \mathrm{~N}$ signatures among 4 rat bone elements from Layer 4.

A diet-induced anomaly was also suggested for a difference of $~ 500 \mathrm{yr}$ between 2 "apparently associated rat bones" (Anderson 2000:245; Smith and Anderson 1998:90) at Pleasant River if the sample set was indeed not from 1 individual (Beavan-Athfield and Sparks 2001b; Beavan-Athfield et al. 2001a). Anomalous rat bone ages were not confined to the New Zealand laboratory; of 2 rat bones dated by Oxford from the Pleasant River site, only 1 result (515 \pm 55 BP, OxA6744) was within the acceptable range set by pooled charcoal ages for Pleasant River (639 \pm 57 BP; Beavan-Athfield and Sparks 2001a), with a second (959 \pm 60 BP, OxA6743; Smith and Anderson 1998) having an enriched $\delta^{15} \mathrm{~N}$ of 17\%o, in the range of marine-based birds (Beavan-Athfield and Sparks 2001a:804). 
In addition to our research on diet-induced anomalies, internal laboratory testing included 2 modern Rattus norvigicus run in 1995 (NZA-5875 and -5876), which returned bomb carbon-affected ages that accurately reflect known date of death to within $5 \mathrm{yr}$ (points 14-15, Figure 2). If a processing, contamination, or analysis effect was operating, it did not occur in these samples, nor did it affect other bone analyzed by the laboratory during this period (Hedges 2000:389). In short, there was no change in laboratory procedure, nor were standard laboratory methods shown to be contributory. Issues such as contamination from ultrafilters (Bronk Ramsey et al. 2004) did not affect Rafter, as Rafter did not use ultrafiltration on rat bone samples, and as part of standard laboratory practice runs background tests on processing equipment (Beavan Athfield et al. 1999; Beavan Athfield et al. 2003). The issue of reliability for the rat bone results does not appear to be one of laboratory practice in producing the dates, but rather of how the results should be interpreted given the evidence for variable, diet-induced ${ }^{14} \mathrm{C}$ offsets in this and other species (Beavan-Athfield and Sparks 2001b; Beavan-Athfield et al. 2001b; Higham et al. 2005).

Given the efforts of Rafter to examine the issue since 1995, and an independent review of Rafter treatment and analysis regimes (Hedges 2000), the "underlying laboratory problem" comment cannot be substantiated. It is unfortunate that Higham et al. (2005), who make an important contribution to the incidence of diet-induced radiocarbon anomalies, should comment on a laboratory's reliability without adequately citing the relevant literature.

\section{REFERENCES}

Anderson AJ. 1991. The chronology of colonization in New Zealand. Antiquity 65(249):767-95.

Anderson AJ. 2000. Differential reliability of ${ }^{14} \mathrm{C}$ AMS ages of Rattus exulans bone gelatin in South Pacific prehistory. Journal of the Royal Society of New Zealand 30(3):243-61.

Anderson A. 2004. The age disconformity in AMS radiocarbon results on Rattus exulans bone. New Zealand Journal of Archaeology 24(2002):149-56.

Beavan NR, Sparks RJ. 1998. Factors influencing the radiocarbon ages of the rat Rattus exulans. Radiocarbon 40(2):601-13.

Beavan-Athfield N, Sparks RJ. 2001a. Dating of Rattus exulans bone from Pleasant River (Otago, New Zealand): testing the effect of burial contamination. Journal of the Royal Society of New Zealand 31(4): 795-800.

Beavan-Athfield NR, Sparks RJ. 2001b. Dating of Rattus exulans and bird bone from Pleasant River (Otago, New Zealand): radiocarbon anomalies from diet. Journal of the Royal Society of New Zealand 31(4):801-9.

Beavan-Athfield N, Sparks RJ. 2001c. Bomb carbon as a tracer of dietary carbon sources in omnivorous mammals. Radiocarbon 43(2B):711-22.

Beavan-Athfield N, McFadgen BG, Sparks RJ. 1999. Reliability of bone gelatin AMS dating: Rattus exulans and marine shell radiocarbon dates from Pauatahanui midden sites in Wellington, New Zealand. Radiocarbon 41(2):119-26.

Beavan-Athfield N, McFadgen B, Sparks R. 2001a. Radiocarbon age variation in bone and tissue from variable dietary effects. In: Proceedings of the 7th Aus- tralasian Archaeometry Conference. Auckland: University of Auckland. p 31-44.

Beavan-Athfield N, McFadgen BG, Sparks RJ. 2001b. Environmental influences on dietary carbon and ${ }^{14} \mathrm{C}$ ages in rats and other species. Radiocarbon 43(1):714.

Beavan Athfield N. 2004. Reliability of ${ }^{14} \mathrm{C}$ AMS dating of rat and bird bone: implications for the timing of New Zealand Holocene vertebrate extinctions. In: Higham T, Bronk Ramsey C, Owen C, editors. ${ }^{14} \mathrm{C}$ and Archaeology: Proceedings of the Fourth Symposium, Oxford. Oxford University School of Archaeology Monograph 62. Oxford: Oxbow Books. p 105-18.

Beavan Athfield N, Sparks R, Holdaway R, Cooper J. 2003. Testing possible processing contamination associated with the AMS dating of rat bone. Abstracts and Programme of the 18th International Radiocarbon Conference, Wellington 2003. p 187.

Bronk Ramsey C, Higham TFG, Bowles A, Hedges R. 2004. Improvements to the pretreatment of bone at Oxford. Radiocarbon 46(1):155-63.

Hedges REM. 2000. Appraisal of radiocarbon dating of kiore bones (Pacific rat Rattus exulans) in New Zealand. Journal of the Royal Society of New Zealand 30:385-98.

Higham T, Petchey F. 2001. Response to "Publication of supplementary data for ${ }^{14} \mathrm{C}$ AMS ages." Journal of The Royal Society of New Zealand 31:454-6.

Higham T, Anderson A, Bronk Ramsey C, Tompkins C. 2005. Diet-derived variations in radiocarbon and stable isotopes: a case study from Shag River Mouth, New Zealand. Radiocarbon 47(3):367-75. 
Holdaway RN. 1996. Arrival of rats in New Zealand. Nature 384(6606):225-6.

Holdaway RN. 1999. A spatio-temporal model for the invasion of the New Zealand Archipelago by the Pacific rat Rattus exulans. Journal of the Royal Society of New Zealand 29(2):91-105.

Holdaway RN, Anderson AJ. 1998. ${ }^{14} \mathrm{C}$ AMS dates on Rattus exulans bones from natural and archaeological contexts on Norfolk Island South-west Pacific. Archaeology in New Zealand 41(3):195-8.

Holdaway RN, Beavan NR. 1999. Reliable ${ }^{14}$ C AMS dates on bird and Pacific rat Rattus exulans bone gelatin, from a $\mathrm{CaCO}_{3}$-rich deposit. Journal of The Royal Society of New Zealand 29(3):185-211.
Holdaway RN, Worthy TH. 2001. Publication of supplementary data for ${ }^{14} \mathrm{C}$ AMS ages. Journal of The Royal Society of New Zealand 31:453-4.

Holdaway RN, Roberts RG, Beavan-Athfield NR, Olley JM, Worthy TH. 2002. Optical dating of quartz sediments and accelerator mass spectrometry ${ }^{14} \mathrm{C}$ dating of bone gelatin and moa eggshell: a comparison of age estimates for non-archaeological deposits in New Zealand. Journal of the Royal Society of New Zealand 32(3):463-505.

Smith IWG, Anderson AJ. 1998. Radiocarbon dates from archaeological rat bones: the Pleasant River case. Archaeology in Oceania 33:88-91. 